Article

\title{
Investigating the Role of Customer Co-Creation Behavior on Social Media Platforms in Rendering Innovative Services
}

\author{
Ali Moghadamzadeh ${ }^{1, *}$, Pejman Ebrahimi ${ }^{2}$, Soodabeh Radfard ${ }^{3}$, Aidin Salamzadeh ${ }^{3}$ and \\ Datis Khajeheian ${ }^{3}$ (D) \\ 1 Department of Curriculum Development \& Instruction Methods, Faculty of Psychology and Educational \\ Sciences, University of Tehran, Tehran 141556311, Iran \\ 2 Doctoral School of Management and Business Administration, Szent Istvan University, 2100 Budapest, \\ Hungary; pejman.ebrahimi77@gmail.com \\ 3 Department of Business Management, Faculty of Management, University of Tehran, Tehran 141556311, Iran; \\ s_radfard@yahoo.com (S.R.); salamzadeh@ut.ac.ir (A.S.); khajeheian@ut.ac.ir (D.K.) \\ * Correspondence: amoghadamzadeh@ut.ac.ir
}

Received: 17 July 2020; Accepted: 20 August 2020; Published: 26 August 2020

\begin{abstract}
The emergence of social media platforms as the main representatives of Web 3.0 applications significantly impacts the co-creation activities among enterprises, customers, and other stakeholders, and has enabled firms to benefit from creativity and ideas of their users and customers for developing and rendering innovative services. This study aims to investigate how the co-creation activities of users on social media platforms have an effect on the enterprises' innovative services. For this purpose, the authors surveyed customers of innovative services who used social media platforms to meet their needs from the enterprises that innovatively offer such services. An online questionnaire was designed and distributed among the sample of customers, and 505 completed questionnaires were analyzed following the PLS-SEM approach. The findings revealed that customer citizenship behavior and customer participation behavior on social media platforms positively affect the rendering of innovative services. Findings also highlighted that an increase in social co-creation activities, as moderator, positively affects customer citizenship behavior on service innovativeness, and negatively affects customer participation behavior on service innovativeness. The findings of this research could be useful for entrepreneurs and managers of the enterprises that offer innovative services to efficiently use social media tools to benefit from the customers' co-creation activities and to perform more competitively and sustainably in a hostile business environment.
\end{abstract}

Keywords: co-creation; social media platforms; innovative services; imitative innovation; behavioral approach; web 3.0

\section{Introduction}

The importance of co-creation activities in advance of innovation in different types of firms has been highlighted in many research studies [1-14]. These types of activities consider customers as a vital resource for enterprises to grow and compete in the volatile, uncertain, complex, and ambiguous (VUCA) world [15-19]. It has become crystal clear that customer engagement in all the activities of the firms-including production, distribution, new product and service development, and similar ones-could improve the profitability of these firms [20-28] and, more importantly, the sustainability of the firm business in the hostile business environment. Due to the benefits of co-creation activities, marketing departments of the firms are paying more attention to interacting with customers [26]. This is a reason why putting more emphasis on this intangible asset moves firms toward the concept 
of co-creation [29]. In line with conventional marketing methods, value co-creation more explicitly considers customers as an integral part of the firm, which creates more valuable relationships and interactions that go beyond consumer goods and services by customers [20-29]. In other words, for the firms that appreciate value co-creation activities, the customer is not merely an external agent, but also an internal agent and a critical partner of the firm [30,31]. This is how firms obtain competitive advantage and also absorb customer ideas in order to develop new products and services [32-36]. Such efforts make firms more capable of rendering innovative services [11,37]. In a recent study, Yen et al. [38] connected the innovativeness of the firm to their customer citizenship and customer participation behaviors. They also considered customer engagement as key to improving these two.

While the invention of the internet (known as Web 1.0, web of cognition) [39] revolutionarily changed the business environment, the introduction of social media platforms (called Web 2.0, web of connection) was another dramatic change that significantly affected businesses and resulted in the birth of media entrepreneurship [40-56]. One of the most important changes that happened due to such technological advances was the ease of access of small enterprises to the business innovations that are successfully implemented in other markets $[57,58]$. There is a long list of innovative services that were first tested and conducted in developed countries and then quickly copied in other countries. This is an advantage for the enterprises to not invest heavy capital and time and resources to test a novel innovation in a market and possibly lose [37]. In the same vein, a new type of innovation has been coined as imitative innovation, along with radical innovation and incremental innovation [37]. Numerous enterprises in the developing countries take the idea of a previously successfully tested innovation on the other markets and implement them-sometimes with some levels of localization-to the local market [55,59]. As an example, in almost every country that is connected to global communication, there are online services provided by local enterprises that are clones of successfully implemented innovations in other markets. In this research, we call these services online innovative services, and study how providers of such services can benefit from the co-creation behaviors of customers.

Further advances of digital technological communications introduced a new generation of web, which is called Web 3.0, or web of co-creation or collaboration [39]. This generation is based on collaborative technologies that enable users to cooperatively work on projects or participate in the creation of values. The concept of platform businesses has roots in this generation of web, although its origin dates back to credit cards [60]. The logic of platforms is to provide a ground for co-creation activities and value proposition [61]. Because of the popularity of smart phones as ubiquitous media in people's pockets [62], individuals use social media in different activities of everyday life, from health [63-66] to travel [67-70], and a considerable amount of users' time are spent in different types of social platforms, including marketplace, crowdsourcing, social media, and other types of social platforms $[60,61]$. Such level of engagement with social platforms creates valuable big data that provide users' patterns of behavior [71-73] for enterprises. Therefore, social media platforms that represent Web 3.0 are the grounds for co-creation activities and collaboration among customers, organizations, and other stakeholders, as well as a source for understanding the customers' needs [74-76].

In spite of such capabilities, several studies show that most enterprises are unable to leverage the potential of social media platforms for co-creation activities, and the usual functions of Web 2.0 social media for connection with their customers normally suffice [61]. Such lack in the use of Web 3.0's abilities deprives enterprises from the ideas, insights, and creativity of users and customers to develop new services to address their needs and, therefore, the firm will be behind the competitors $[4,11,60]$.

Based on the abovementioned, while social media platforms are a venue for small firms to propose value to customers through the delivery of innovative services, these platforms are also a foundation for the co-creation behavior of users of the innovative services to participate in the value proposition process and to help with the enhancement of such services. While the concept of innovation is a complicated issue on its own, in the service domain, the subject of rendering new services via co-creation activities is even more complicated [11]. For this reason, the present study aims to investigate the role of such co-creation behavior of customers in the development and enhancement of innovative 
services that small firms and enterprises provide for the market. The importance of this research lies in the fact that the providers of imitative innovative services have low share in the creation of value by product or service design, process, and use, but they can add innovative aspects to the delivery of the service. To do this, the present research adopted a behavioral approach and considers two measures of customer citizenship behavior (CCB) [76] and customer participation behavior (CPB) [77] as the main variables of customers' participation. Moreover, this study is focused on the service providers that offer an innovation in product, process, idea, or feature of services that the majority of the providers in the local and regional market do not deliver. It is not necessary that they have invented such innovation, but they can imitate and copy the innovation from other markets or geographical regions. Such factors are critical for service innovation in any entrepreneurial ecosystems [78].

The problem statement of this study is "how do customers' value co-creation activities on social media platforms affect the rendering of innovative services that entrepreneurial firms deliver to the market?" The framework is developed by a review of the existing literature; then, it is tested through a structural equation modelling (SEM) approach. Afterward, the materials and methods are discussed, and the results are elaborated. Finally, the paper concludes with some remarks on how value co-creation affects the better rendering of innovative services on social media platforms.

\section{Theoretical Background and Hypotheses}

\subsection{Value Co-Creation Behavior}

The concept of co-creation was first introduced in the 1990s and has drawn the attention of a large number of scholars [24]. Several papers and books were published, and the concern of engaging customers in order to produce innovative products and render innovative services was highlighted in this field [26]. Edvardsson et al. [79] consider value co-creation as a result of customers' or stakeholders' contributions in creating value for the firm. Vargo and Lusch argue that value is created commonly and, to some extent, equally by a firm and its customers in a continuous process [80]. In their point of view, value co-creation takes place by both parties, and not just by one [81]. Value co-creation is not only about the interaction among the customers and employees of a firm, but is also related to the interaction and communication among different customer segments of a typical firm or their relationship with virtual environments [82], especially on media platforms, in which interactions are an integral part of their nature [83]. Xie et al. put more emphasis on customers' behavior in creating value and argue that in such a process, customers' and firms' needs are met by following a collaborative process [84].

On the other hand, new product and service development activities are conducted through collaborating with customers and sharing their visions with firms [11]. Indeed, any successful product or service development is proved to be a function of knowing customers' needs [85]. This is of paramount importance when it comes to innovative products and services, as such products and services have a variety of details, which makes providing or offering them impossible for firms without understanding customers' new ideas and needs [86]. As mentioned earlier, Yi and Gong have introduced two types of value co-creation behaviors: i.e., (i) customer citizenship behavior, and (ii) customer participation behavior [87]. The first one is a voluntary behavior that is not necessary for the successful production of goods and services, but improves the status of a firm [76]. The second one is the participative behavior of customers, which is necessary for producing winning goods and services [23].

\subsubsection{Value Co-Creation Behavior and Rendering Innovative Services}

Innovation is the key to success in this competitive world. There is a continuum of innovative activities that range from radical to imitative innovation. According to this approach, there might be a range of innovative services that could be rendered to customers [87]. The more creative a firm is, the more it becomes able to co-create value. According to the literature, some scholars have used value co-creation and co-innovation interchangeably, as these two are, in some ways, entangled 
phenomena. To some scholars, service innovation is viewed as a function of the customer's role in value co-creation [87]. By performing more actively, customers will be able to be a part of value co-creation in companies, especially when they are receiving an innovative service that depends highly on their perception of and views toward such a service [6,21,22]. Innovative services are often a function of firms' and customers' competences and prerequisites of the service offerings, as well as how these two parties-i.e., firm and customer-interact to co-create value [88,89].

Den Hertog [90] considers four dimensions for describing innovative services, which includes the following aspects [89]: (i) service concept: while products are typically tangible, services lack this characteristic, but, generally, service innovations are visible, as they touch the emotions and the minds of customers. However, it might depend on customers' perception of the service and the extent that the service concept is understood. It should be mentioned that not all service innovations convey novel conceptual aspects; however, it is clear that if a service providing firm puts enough effort into it, it would be more visible to its customers than in manufacturing firms. (ii) Client interface: the design of the interface between service providers and customers is another dimension of service innovation. Despite innovation studies neglecting client interface, it is critical to consider its role due to their focus on mass manufacturing and not service innovations, especially in value co-creation. The way the client interface acts affects how customers would become a source of innovation in the value co-creation process. Such a platform might make a firm able to engage in a variety of activities, such as co-design, co-production, or even co-service provision. (iii) Service delivery system/organization: this system deals with all internal activities that a firm could take care of and manage in order to let employees of the service providing department have enough authority to develop and render innovative services properly. This system is considered as a part of the customer relations process. This aspect refers to the linkage between the last two aspects. (iv) Technological options: although this aspect is of paramount importance, it should be noted that service innovation is not necessarily dependent on technological options-yet technological issues and innovative services could be highly related. It could be marginally considered as a facilitator of innovative services or drive innovation. The more that firms become aware of technological changes, the more they will become able to respond to them and design and render better services. Cheng et al. [91] provide a better understanding of the concept of service innovativeness and measure it according to the customers' perceptions, new benefits associated with innovative services, its features, unconventional problem solving, and its brand-newness. Their approach is used in this study, as it covers the required specifications, which have been mentioned in the extant literature.

\subsubsection{Customer Citizenship Behavior}

This type of behavior is "an extra-role customer's behaviour, which is not really required for value co-creation, but if performed, it will give supplementary value to the firm" [86]. Such behaviors improve the quality of social and mental environments in the workplace and finally lead to an improved performance of the firm [76]. These behaviors are mainly proposed voluntarily by customers, and there is no pressure on them to act so in the long term. Thus, it is affected by external rather than internal factors of the firm. These behaviors are categorized into four groups, as follows [86]: (i) helping: this refers to the actions done to help other customers, since, in a typical co-creation process, customers mostly help each other instead of asking for help from employees of the firms. They show empathy toward each other, as they are receiving a similar service or buying a similar good. Thus, they must have similar needs that make them closer to feel that they have social responsibility. (ii) Feedback: customers provide employees of the firms with relevant information about how they feel while using a specific service or buying a specific good. They do this to receive better services or more quality goods in the long run. Customer feedback and their suggestions and views make firms more capable, and, thus, their performance will be improved. (iii) Tolerance: customers tolerate, to some extent, some of the imperfections and pains they feel through their buying experience. Sometimes, services might not be as perfect as they would like. Therefore, their tolerance level might protect the profitability 
and market share of the firm, or vice versa. (iv) Advocacy: this means that customers recommend goods or services to others, such as their family members, friends, acquaintances, or colleagues. Thus, such customers might become more loyal and passionate about the goods or services that a firm produces or renders. This is critical to promote the firm's brand and credit, as well as its quality. Moreover, it helps the firm to make a better evaluation of its business model. These four aspects of customer citizenship behavior ensure the success or failure of the firms. The more that such behaviors become popular, the better a typical firm might be able to act in this competitive world. Therefore, one could mention customer citizenship behavior as a multi-dimensional phenomenon. As one could see, such behaviors will add extraordinary value to the firm but are not inevitably required for value co-creation. Some scholars have compared this phenomenon with concepts such as organizational citizenship behavior. However, it should be noted that customer citizenship behavior is an extra role of customers standing outside or close to organization boundaries [25].

The extant literature has marginally investigated the relationship between customer citizenship behavior and the rendering of innovative services. For instance, Aggarwal [92] connected these two concepts to highlight the customer-based corporate reputation and its impact on the quality of its products and services. She implicitly pointed out that customer citizenship behavior could impact the quality and innovativeness of the products. Despite the implicit notions of scholars such as Yen et al. [38], Heidenreich and Handrich [93], and Jaakkola and Alexanderh [94] regarding such a relationship between customer citizenship behavior and innovative services of the firms, limited studies, such as the one conducted by Yen et al. [38], have explicitly investigated this relationship. Nevertheless, the relationship between different aspects of customer citizenship behavior and innovative services is mentioned to some extent in the literature. For instance, it is argued that customers are more likely to provide valuable feedback, promote the advantages of the firms' services and help others, and tolerate service failures if they feel that the firm is acting innovatively and provides innovative products and service [95]. Therefore, we propose the following hypothesis to investigate such relationships in an emerging market.

Hypothesis 1 (H1). Customer citizenship behavior on social media platforms affects the rendering of innovative services.

\subsubsection{Customer Participation Behavior}

The second type of behavior is customer participation behavior, which is "an in-role customer's behaviour essential for value co-creation" [86]. It should be noted that participation is a behavioral concept that engages customers in providing resources or acting actively in the process of product or service development and delivery. Such behavior is participative in nature, which emerges during the value co-creation process. According to a general categorization, it is reflected in the four dimensions as follows [86,87,96]: (i) information seeking: information is a critical issue for customers to make their buying decision. It should be noted that similar information might be interpreted differently by customers. Therefore, customers initially need to seek relevant information. This is vital for them, as it decreases the uncertainty level and provides customers with a better understanding of their peripheral environment. Moreover, it provides a fertile ground for customers to engage in the value co-creation process. (ii) Responsible behavior: such behavior is an integral part of the value co-creation process, as it makes customers responsible regarding how they act and what they shall do as a customer to receive a better service or a higher quality product. Customers would become aware of the firm's rules and regulations, as well as policies, and would optimally act as an active player in the value co-creation process. (iii) Information sharing: information sharing is another aspect of customer participation behaviors that makes it possible for the customers and employees of the firms to become aware of what, exactly, is going on in the firm and its peripherals. Customers share their information with employees, and due to a better mutual understanding and sharing of similar values, performance measures will be improved and the firm would be able to act more efficiently. In addition to this, customers' needs and 
preferences will be met more perfectly, and they will become more satisfied. (iv) Personal interaction: personal interactions among customers and employees make them feel more comfortable, and, thus, friendship, respect, and positive thinking will be shaped accordingly. In this way, customers feel better and engage more actively in the value co-creation process.

Scholars, such as Yen et al. [38], have highlighted the connection between innovativeness and customer participation behavior more explicitly. Moreover, Heidenreich and Handrich [93] and Jaakkola and Alexander [94] followed a service-dominant logic and revealed a positive association between innovativeness and customer participation behavior. Hwang et al. [97] also believe that the innovativeness of services and customer participation behavior are correlated and customers will interact more proactively with firms with innovative products. Nevertheless, a few studies have considered such a relationship on social media platforms. For instance, Buhalis and Foerste [98] investigated this relationship in the tourism industry and highlighted the use of smart technologies to strengthen such a relationship. Therefore, we propose the following hypothesis to investigate this relationship in an emerging market.

Hypothesis 2 (H2). Customer participation behavior on social media platforms affects the rendering of innovative services.

\subsection{Social Co-Creation as the Moderator}

Social media platforms provide several sources of detailed information about a variety of topics, goods, and services, which could pave the way for value co-creation activities. In fact, value co-creation is facilitated on social media platforms, and, therefore, it is more possible to offer innovative services accordingly. In the extant literature, social co-creation is referred to as the co-creation of value by customers on social media $[99,100]$. By using social media, customers have changed their role from passive entities to active or even proactive agents who could facilitate the offering of innovative services. This concept is defined explicitly by Kennedy and Guzmán as a phenomenon that is shaped by the following factors [101]: (i) peer pressure: this element deals with what extent peers encourage an individual to act as per a typical pressure group's instructions. In fact, it shows whether people on social media are affected by their peers or not. (ii) Popularity: this shows how popular an individual is on social media. Indeed, popularity might affect the position of an individual on social media. (iii) Trend: this shows how trends might affect the behavior of the members of typical social media. Such trends might be created internally or externally. (iv) Social status: this shows whether a person is at the core of a network with several ties or not. The more a person becomes a central point in social media and its networks, the more he/she becomes able to create value.

Despite the importance of social co-creation in improving customer engagement and, therefore, strengthening the relationship between customer citizenship and participation behaviors and service innovativeness, such a moderating role has not been empirically investigated in the literature [99,100,102]. In a recent work, Roberts et al. [103] highlighted the importance of social co-creation networks in improving consumers' motivations in order to increase innovation through co-creation activities in selected firms. Therefore, it is interesting to see if this moderating role affects the relationship between the dimensions of value co-creation behavior and the rendering of innovative services on social media platforms, especially when one intends to examine the different aspects of value co-creation behavior. The following hypotheses are proposed accordingly:

Hypothesis 3 (H3). The effect of customer citizenship behavior on social media platforms on the rendering of innovative services is moderated by social co-creation.

Hypothesis 4 (H4). The effect of customer participation behavior on social media platforms on the rendering of innovative services is moderated by social co-creation. 


\subsection{Theoretical Framework}

Figure 1 shows the theoretical framework of the research, which was developed by researchers in an exploratory way, as explained. It is followed by two main hypotheses and four sub-hypotheses. The hypotheses are proposed according to the main subjects, which have not been clearly studied and investigated in the existing literature of the field.

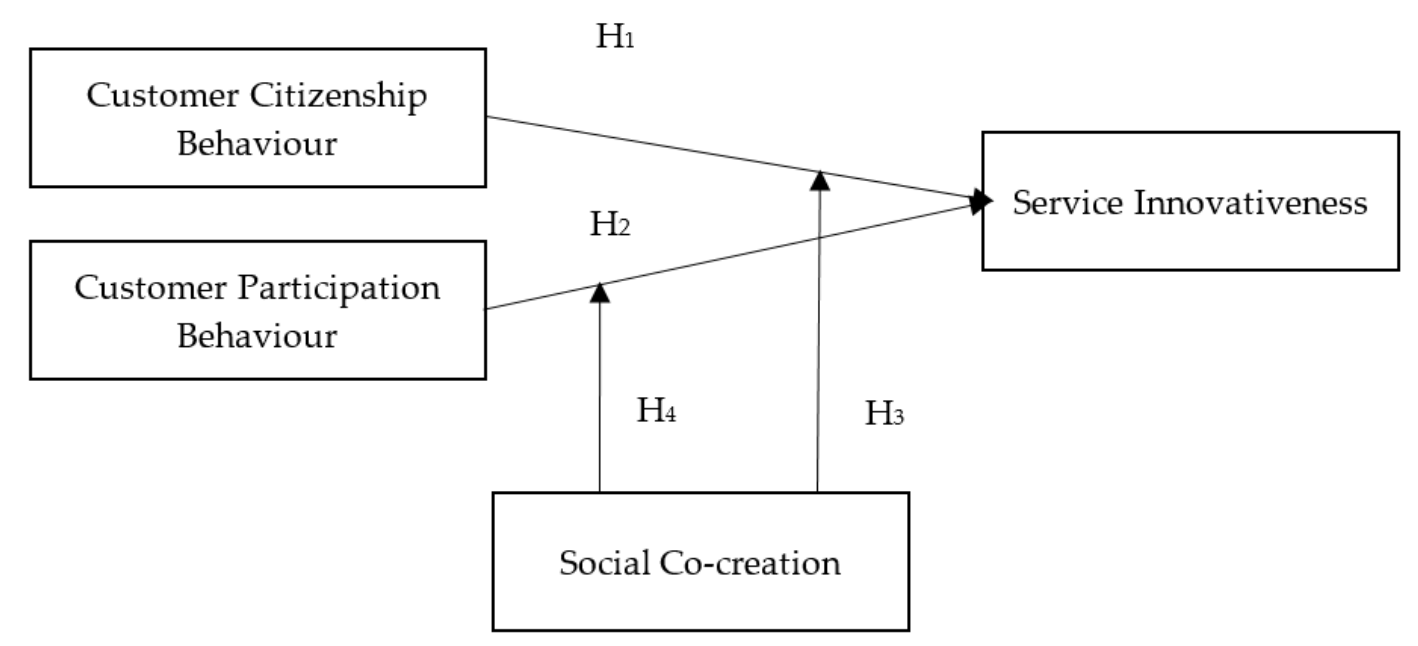

Figure 1. Theoretical framework (self-elaborated by the authors).

\section{Materials and Methods}

\subsection{Sample Size and Variable Measurement}

The research population consisted of the customers of selected innovative services who used Instagram, a dominant social media platform in the country, and Divar, a marketplace platform where businesses and individuals announce their services for free. The innovative services consisted of specific enterprises with a reputation and record of activity as a service platform, including one genetic test service, three insurance provider startups, two automobile repairing services, three house cleaning services, one steam-wash carwash service, two online laundry services, three maintenance services, and five online education services. The criterion for being "innovative" in the service was to deliver an addition to the service that is not commonly delivered to customers by the majority of providers of such services. For example, issuing insurance online, sending a van to take the coats and clothes and return them after washing, delivering a genetic map of the customer for understanding the best diet and exercise plan, etc. By setting such a criterion, twenty online services were selected and their customers were identified as the samples of the study.

To collect data, an online questionnaire was developed and distributed by the authors. The researcher-made questionnaire was designed by use of measures from previous research. To ensure that the questions were clear and understandable, a pre-test was conducted. An analysis of the results showed that some of the questions were too close and unrecognizable for the respondents. These questions were removed and a questionnaire of 25 closed-ended questions, in addition to general demographic information, was finalized. Six questions measured each of the customer's participation behavior (information seeking, information sharing, responsible behavior, and personal interaction) and customer citizenship behavior (feedback, advocacy, helping, tolerance) variables (adapted from Yi and Gong [87]). Moreover, social co-creation (peer pressure, popularity, trend, social status) as a moderator variable was measured by four questions (adapted from Cheng et al. [91]). Finally, six questions were used to measure innovative services as the dependent variable (adapted from Kennedy and Guzmán [101]). A five-point Likert scale was used and divided the responses from 5 ("strongly agree") to 1 ("strongly disagree"). The questions were asked in the Persian language 
and for each question, an example was provided for the better understanding of the respondents. This questionnaire is presented in Appendix A.

To determine the sample size, SPSS Sample Power software was used. The largest number of variables in the set multivariate regression model was three, considering the confidence level of $95 \%$, power of increment of 0.99 , and increment to R-squared of 0.05 . According to the research model, the minimum sample size was 451. In order to improve the quality of responses, we continued collecting the data to receive more questionnaires $(n=525)$; then, we eliminated the incomplete ones, and finally, 505 completed questionnaires were analyzed. Most of the respondents $(49.7 \%)$ were between 25 to 34 years old, and most of them were male (59.6\%). Meanwhile, a majority of the respondents held a master's degree $(36 \%)$.

The survey was online for about three months in 2020 (March-May) on a google doc webpage. We distributed this questionnaire online through social media platforms by sending its URL to the customers of selected innovative services that left comments on the social media pages of selected service providers. We also posted the URL to our social media accounts on Instagram, Twitter, and Facebook and requested our connections to participate in this survey if they had ever purchased services from the selected online service providers. Furthermore, we re-sent the invitation every month during the data collection period to find fresh respondents.

\subsection{Validity and Reliability}

The content validity of the questionnaire was approved by expert scholars with records of publishing research in the field, who reviewed the questions in detail. As explained, after a pre-test and analysis of the resulting data from 25 respondents, several questions were removed and then the final questionnaire was presented to the experts for approval. Convergent validity was analyzed according to outer loadings and an average of variance extracted (AVE) index. Therefore, as shown in Table 1, the outer loadings were more than 0.4 [104,105], and the AVE was above 0.5, and so the convergent validity was approved. The reliability of the questionnaire was evaluated by composite reliability (CR) and DG rho, as shown in Table 1. Some researchers suggested 0.7 and above as the favorable point for CR and DG rho [23,106-108]. Hence, as the value of these coefficients was higher than 0.7 , the reliability of the research tool was confirmed. Moreover, outer VIF values were analyzed. The results revealed that there was no multicollinearity between the designed items, as VIF was not greater than 3.5 [106].

Table 1. Measurement models, convergent validity, reliability, and multicollinearity.

\begin{tabular}{|c|c|c|c|c|c|c|}
\hline Constructs & $\begin{array}{c}\text { Outer } \\
\text { Loadings }\end{array}$ & VIF & AVE & CR & DG rho & Model Type \\
\hline $\begin{array}{c}\text { Customer Participation } \\
\text { Behavior }(\mathrm{SD}=0.581 \\
\mathrm{M}=4.314)\end{array}$ & & & 0.592 & 0.920 & 0.907 & Reflective \\
\hline CPB 1 & 0.805 & 2.198 & & & & \\
\hline CPB 2 & 0.855 & 3.298 & & & & \\
\hline CPB 3 & 0.791 & 2.583 & & & & \\
\hline СРB 4 & 0.770 & 2.011 & & & & \\
\hline CРB 5 & 0.640 & 1.569 & & & & \\
\hline CPB 6 & 0.808 & 2.452 & & & & \\
\hline CPB 7 & 0.692 & 1.774 & & & & \\
\hline CPB 8 & 0.770 & 2.039 & & & & \\
\hline
\end{tabular}


Table 1. Cont.

\begin{tabular}{|c|c|c|c|c|c|c|}
\hline Constructs & $\begin{array}{c}\text { Outer } \\
\text { Loadings }\end{array}$ & VIF & AVE & CR & DG rho & Model Type \\
\hline $\begin{array}{c}\text { Customer Citizenship } \\
\text { Behavior }(\mathrm{SD}=0.583 \\
\mathrm{M}=4.308)\end{array}$ & & & 0.546 & 0.905 & 0.883 & Reflective \\
\hline СCB 1 & 0.794 & 2.671 & & & & \\
\hline ССВ 2 & 0.791 & 2.674 & & & & \\
\hline ССВ 3 & 0.742 & 2.047 & & & & \\
\hline CCB 4 & 0.811 & 2.593 & & & & \\
\hline CCB 5 & 0.620 & 1.704 & & & & \\
\hline СCB 6 & 0.685 & 1.772 & & & & \\
\hline CCB 7 & 0.717 & 1.646 & & & & \\
\hline ССВ 8 & 0.729 & 1.775 & & & & \\
\hline $\begin{array}{c}\text { Social co-creation } \\
(\mathrm{SD}=0.658, \mathrm{M}=4.357)\end{array}$ & & & 0.691 & 0.899 & 0.860 & Reflective \\
\hline SCC 1 & 0.814 & 1.619 & & & & \\
\hline SCC 2 & 0.865 & 2.443 & & & & \\
\hline SCC 3 & 0.838 & 2.109 & & & & \\
\hline SCC 4 & 0.806 & 1.918 & & & & \\
\hline $\begin{array}{l}\text { Service Innovativeness } \\
(\mathrm{SD}=0.556, \mathrm{M}=4.391)\end{array}$ & & & 0.614 & 0.888 & 0.849 & Reflective \\
\hline SI 1 & 0.817 & 1.855 & & & & \\
\hline SI 2 & 0.743 & 1.704 & & & & \\
\hline SI 3 & 0.784 & 1.886 & & & & \\
\hline SI 4 & 0.754 & 1.699 & & & & \\
\hline SI 5 & 0.817 & 1.910 & & & & \\
\hline
\end{tabular}

Notes: AVE, an average of variance extracted; $C R$, composite reliability; $\mathrm{SD}$, std. deviation; $\mathrm{M}$, mean; $\mathrm{CPB}$, customer participation behavior; CCB, customer citizenship behavior; SCC, social co-creation; SI, service innovativeness.

The Fornell and Larcker criterion was used to assess discriminant validity [109]. This indicated the appropriate fitting of the measurement models in terms of discriminant validity at the factor level. Table 2 shows discriminant validity.

Table 2. Discriminant validity.

\begin{tabular}{ccccc}
\hline Constructs & CCB & CPB & SI & SCC \\
\hline CCB & $\mathbf{0 . 7 3 9}$ & & & \\
\hline CPB & 0.734 & $\mathbf{0 . 7 6 9}$ & & \\
\hline SI & 0.720 & 0.693 & $\mathbf{0 . 7 8 3}$ & \\
\hline SCC & 0.617 & 0.674 & 0.710 & $\mathbf{0 . 8 3 1}$ \\
\hline
\end{tabular}

Note: Bold diagonal elements are the square root of AVE.

\section{Results}

In this research, a PLS-SEM approach was followed using the SmartPLS 3 software in order to estimate the measurement and structural model parameters, as well as to test the research hypotheses. In this approach, we examined the structural model by assessing the path coefficients (Figure 2) 
among constructs, and we also calculated the t-statistics (Figure 3) for the hypotheses. We also examined the goodness of fit indexes of the structural model (Table 3). The most important indexes were $R^{2}$ and $R^{2}$ adjusted, which are shown in the table below. Moreover, in order to examine the predictability of the model, the Q2 index-including construct cross-validated redundancy (CC-Red) and construct cross-validated communality (CC-Com) - was used, which should be closer to $1[106,110,111]$. In addition to this, a SRMR value was used as the most important index in order to evaluate the model $[106,107,112]$. The SRMR value in the estimated model and saturated models was reported as 0.078 , which showed the goodness of fit of both measurement and structural models. Moreover, the Akaike information criterion (AIC), Bayesian information criterion (BIC), and Hannan-Quinn information criterion (HQ) indices were highly negative, which showed the fitness of the model.

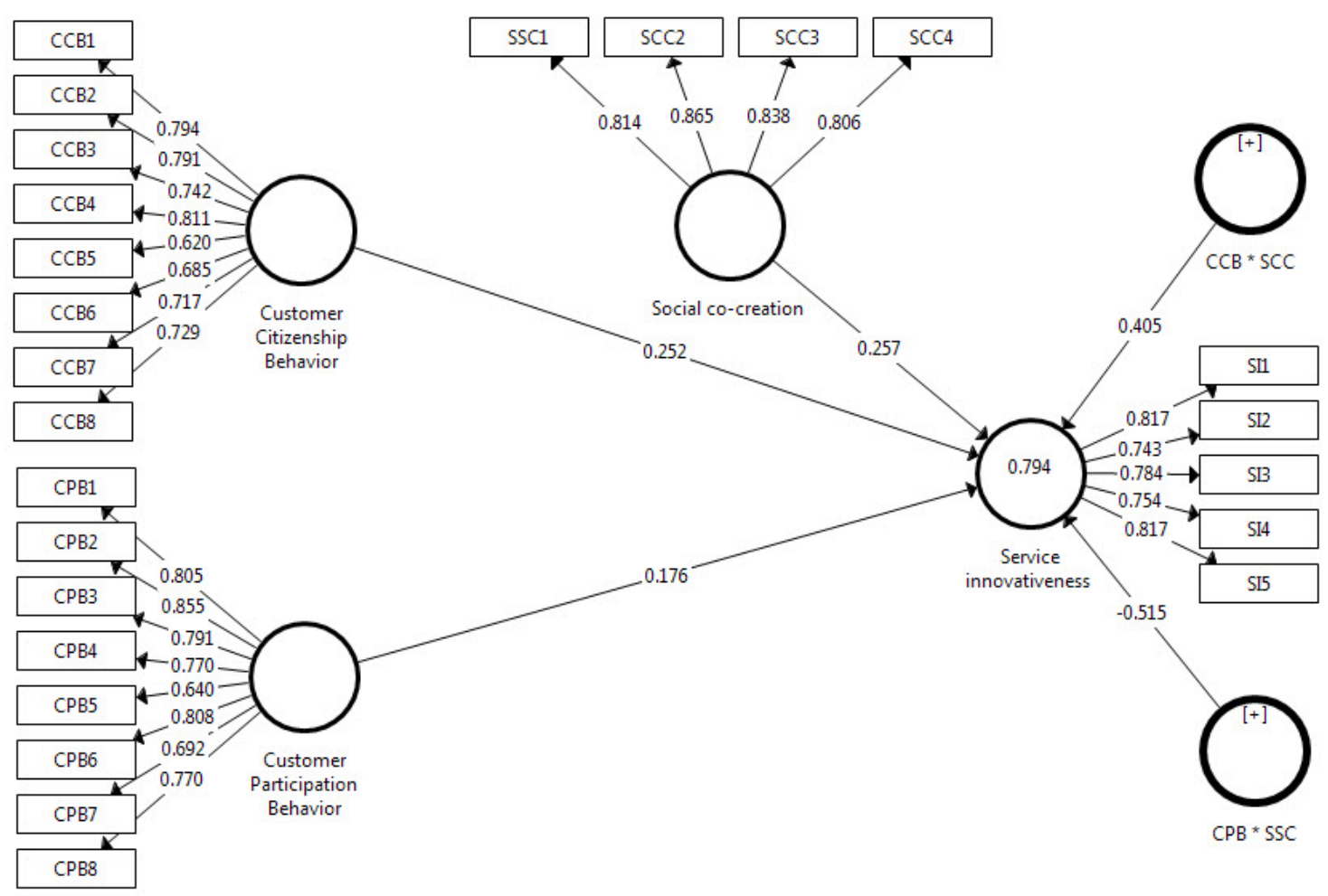

Figure 2. Path coefficients model.

Table 3. Assessment of structural model indicators and model criteria.

\begin{tabular}{cccccccc}
\hline Variable & $\mathbf{R}^{2}$ & $\mathbf{R}^{2}$ Adjusted & CC-Red & CC-Com & AIC & BIC & HQ \\
\hline CCB & - & - & - & 0.416 & - & - & - \\
\hline CPB & - & - & 0.515 & 0.474 & - & - & - \\
\hline SI & $79.4 \%$ & $79.2 \%$ & 0.447 & 0.419 & -786.867 & -761.556 & -776.961 \\
\hline SCC & - & - & - & 0.475 & - & - & - \\
\hline
\end{tabular}

Note: AIC: Akaike information criterion; BIC: Bayesian information criterion; HQ: Hannan-Quinn information criterion.

In order to test the first hypothesis (H1: CCB-SI), the direct effect was examined. According to Figures 2 and 3, this hypothesis was supported (H1: $\beta=0.252$, SD $=0.072, t=3.506, p=0.000$ ). Furthermore, to test the second hypothesis (H2: CPB-SI), the direct effect was examined. According to Figures 2 and 3, this hypothesis was supported (H2: $\beta=0.176, \mathrm{SD}=0.049, t=3.577, p=0.000)$. 


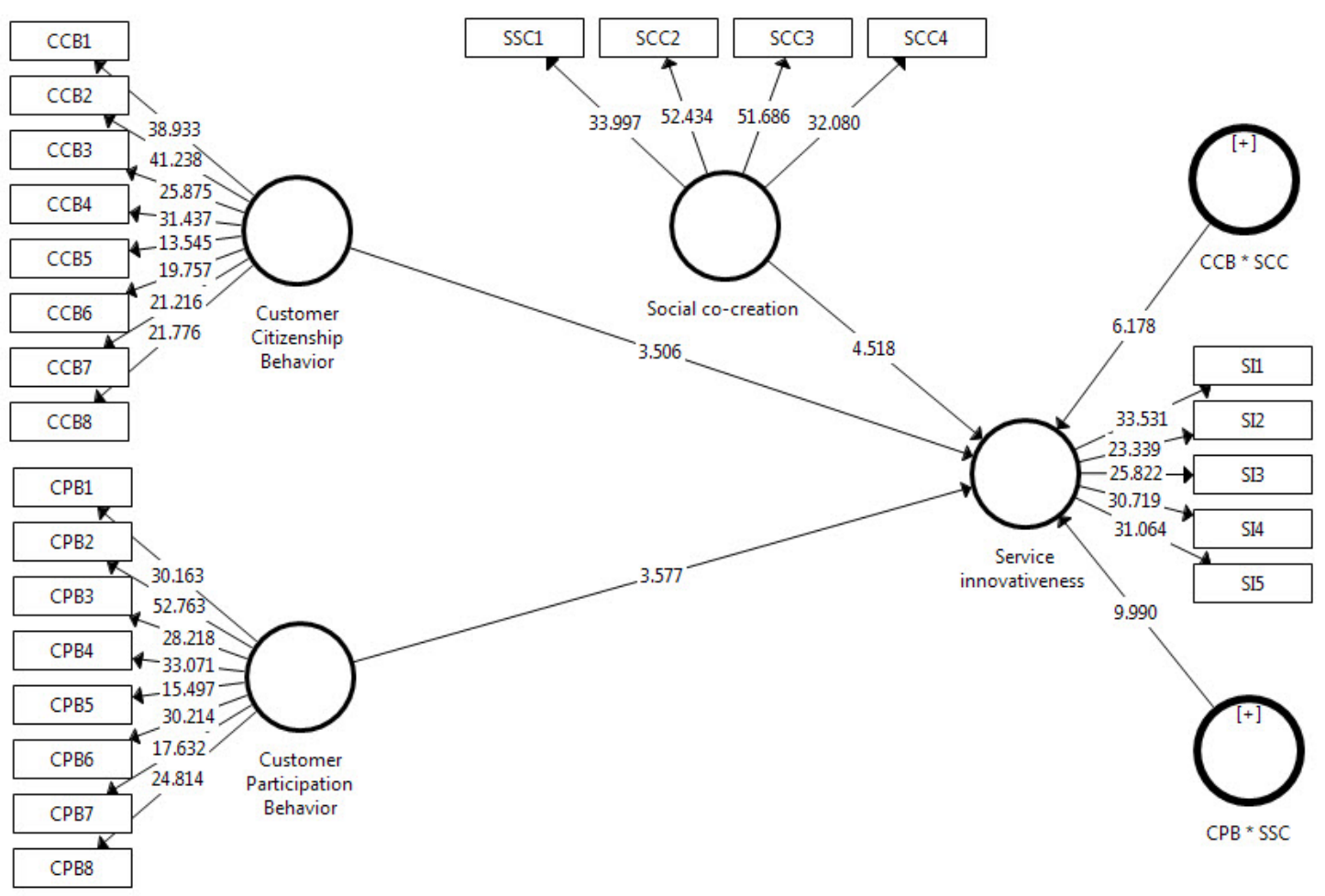

Figure 3. T-statistics model.

In the third hypothesis $(\mathrm{H} 3: \mathrm{CCB} \times \mathrm{SCC}-\mathrm{SI})$, the moderating effect was examined. The product indicators approach was used to test this hypothesis, which showed that this hypothesis was also supported positively (H3: $\beta=0.405, \mathrm{SD}=0.066, t=6.178, p=0.000$ ). Based on the positive coefficients, we could conclude that an increased social co-creation could lead to more of an effect of CCB on SI. Meanwhile, the moderating effect was examined for H4 (CPB $\times$ SSC - SI). This hypothesis was also supported, but negatively ( $\mathrm{H} 4: \beta=-0.515, \mathrm{SD}=0.052, t=9.990, p=0.000$ ). Based on the negative coefficients, we could conclude that an increased social co-creation could lead to less of an effect of $\mathrm{CPB}$ on SI. Plots 1 and 2 show moderating effects with a simple slope analysis. Figure 4 illustrates that an increase in social co-creation (SCC) positively increased the effect of CCB on service innovativeness. On the other hand, Figure 5 elucidates that an increase of one standard deviation in SCC decreased the effect of CPB on service innovativeness. Table 4 shows the results of the hypotheses: all of them were supported with a $95 \%$ confidence level.

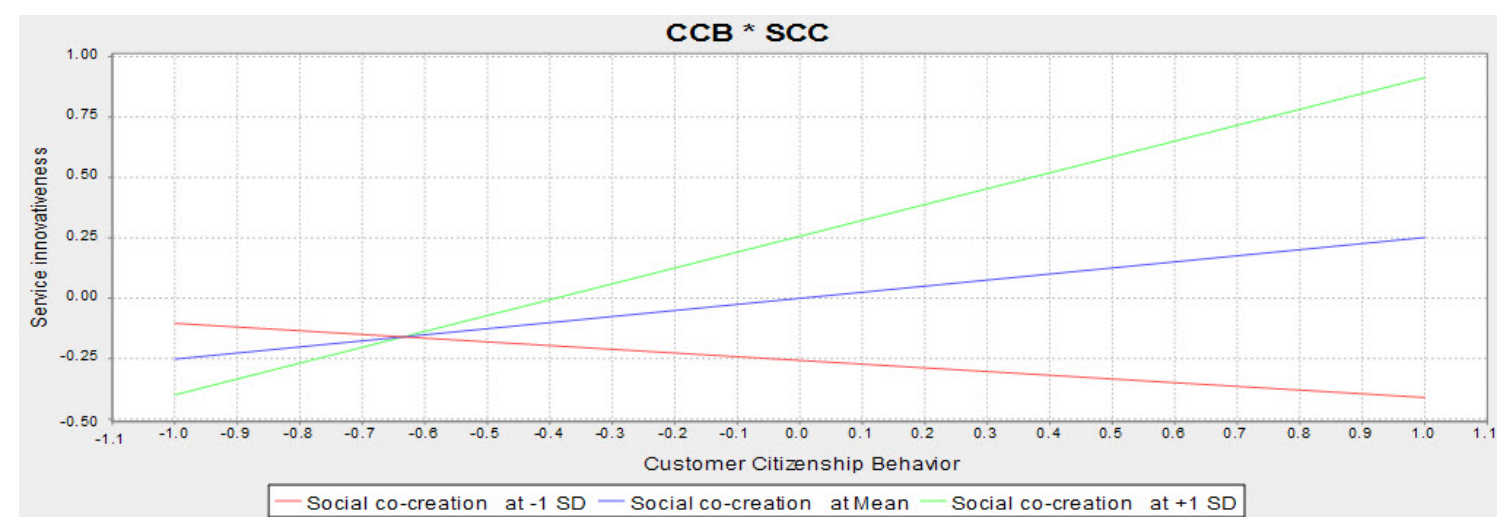

Figure 4. Moderating effect simple slope analysis for H3. 


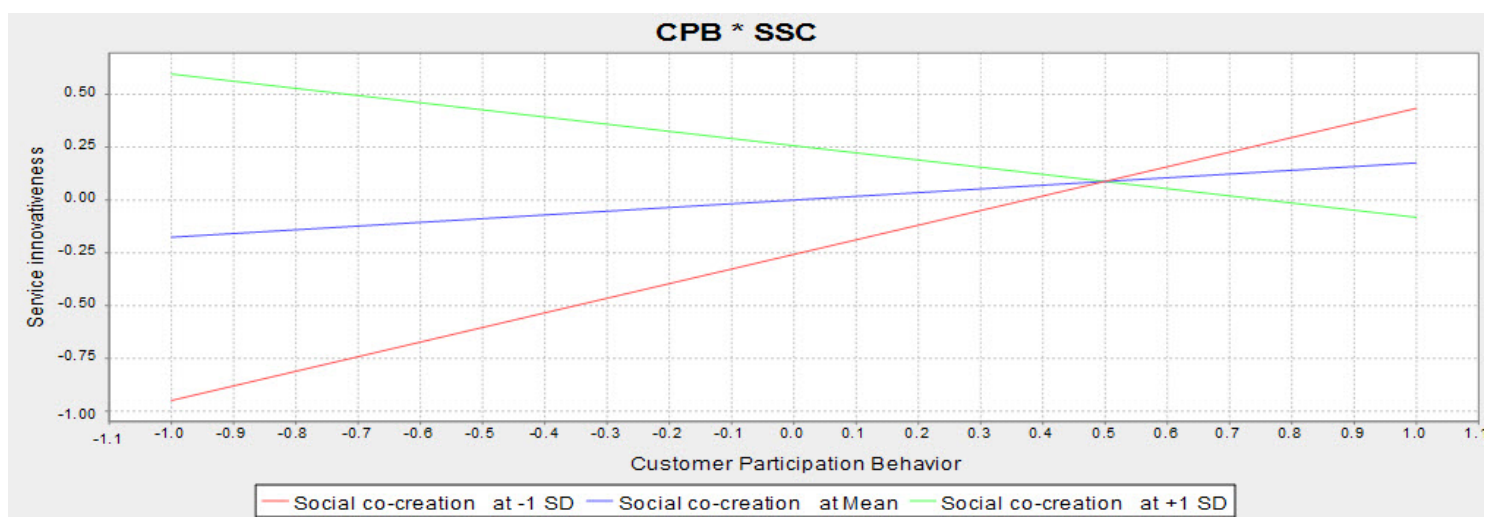

Figure 5. Moderating effect simple slope analysis for H4.

Table 4. Results of research hypotheses

\begin{tabular}{cccccc}
\hline Hypotheses & Path Coefficient & SD & $t$-Statistics & $p$-Value & DECISION \\
\hline H1 (CCB-SI) & 0.252 & 0.072 & $3.506^{* * *}$ & 0.000 & Supported \\
\hline H2 (CPB-SI) & 0.176 & 0.049 & $3.577^{* * *}$ & 0.000 & Supported \\
\hline H3 (CCB*SCC-SI) & 0.405 & 0.066 & $6.178^{* * *}$ & 0.000 & Supported \\
\hline H4 (CPB*SCC-SI) & -0.515 & 0.052 & $9.990^{* * *}$ & 0.000 & Supported \\
\hline Note: $t>1.96$ at ${ }^{*} p<0.05 ; t>2.58$ at & $* * 0.01 ; t>3.29$ at ${ }^{* * *} p<0.001 ;$ two-tailed test.
\end{tabular}

\section{Discussion}

As mentioned earlier, co-creation activities enable firms to better understand the customer's needs and also use the innovative ideas of customers. Such activities are an especially critical issue while rendering new services. Value co-creation behavior dimensions, which include customer citizenship behavior (CCB) and customer participation behavior (CPB), are vital for realizing economic value and, also, their effect on the rendering of innovative services is key. Taking this into account, two other issues might be of paramount importance. Therefore, this study has focused on investigating these relationships to shed light on the possible impacts, as well as the moderating effect of the social co-creation. According to our findings, all the hypotheses are supported, which reflects that both customer citizenship and participation behaviors positively impact the innovativeness of services provided by the studied service providers. In addition, the moderating impact of social co-creation on these relationships is approved. There are interesting findings regarding these effects, which are discussed in the following paragraphs. In summary, the extant literature does not clearly examine these issues; however, some of them are poorly discussed.

The relationship between co-production activities and the rendering of innovative services is explicitly mentioned by Hertog [90]. He considered co-production as a critical issue to be taken into account in service innovation. Koelling et al. [113] also considered value co-creation as a strategy toward innovative services. Their approach does not explicitly highlight the relationship between value co-creation behavior dimensions and the rendering of innovative services; instead, they focused on the actors-i.e., the "successful strategic service innovators." This is in line with the findings of Rajala et al. [114] and Chen et al. [115] in terms of the relationship between value co-creation behavior dimensions and service innovation. In their special issue, Rajala et al. [114] tried to open new areas of research by focusing on the transition from service production to service innovation. Rendering such services on social media platforms is marginally referred to by Yang et al., who measured blog service innovation in social media services, in which value co-creation behavior dimensions were poorly mentioned [89].

The relationship of customer citizenship behavior (CCB) and customer participation behavior $(\mathrm{CPB})$ with the rendering of innovative services is another theoretical contribution of this research $(\mathrm{H} 1$, 
H2). Shamim and Ghazali have studied customer value co-creation behavior in retail, but did not consider their effect on the development of innovative services, especially on social media platforms [86]. Our findings revealed that both customer citizenship behavior and customer participation behavior on social media platforms positively affect the rendering of innovative services. Bidar [116] highlighted the importance of customer citizenship behavior and customer participation behavior in the stages of the innovation process. Her research has become distinguished from other related research works by focusing on a specific research question, in which the importance of social media in rendering innovative services is scrutinized.

In a nutshell, the contribution of the present research is primarily on the moderating effect of social co-creation and how it affects the relationships between independent variables and dependent variables. Firstly, the increase in social co-creation increases the effect of customer citizenship behavior on innovative services. Plot 1 depicts the simple slope of the positive effect of the moderating variable. We argue that the positive effect is due to the items that were asked about in the questionnaire in this regard. For instance, the questions on this part of the questionnaire asked about commenting, feedback, recommending, and assisting. Secondly, the increase in social co-creation decreases the effect of customer participation behavior on innovative services. Plot 2 depicts the simple slope of the negative effect of the moderating variable. We argue that the negative moderating effect of social co-creation is due to the items that were asked in the questionnaire. For instance, the questions on this part asked about being explained, answered, providing requested information, performing required actions, fulfilling responsibilities, and following the orders. This issue was rarely examined in the existing literature, and was merely implicitly noted in some studies: e.g., see $[117,118]$. This shows that social co-creation moderates the role of customer citizenship behavior and customer participation behavior on social media platforms in the development of innovative services, which can make the findings interesting.

\subsection{Managerial Implications}

The findings revealed that managers of service companies who would like to render more innovative services should take advantage of the two dimensions of value co-creation behavior on social media platforms. In order to do so, they might use social media platforms to communicate with their customers proactively and to make required changes in their current services based on the ideas and feedback they receive. In addition to this, managers should use different techniques in order to improve customer participation behavior due to the negative moderating effect of social co-creation. This is important to overcome the possible negative consequences, such as the decrease in practical actions of customers to participate in service innovativeness. Moreover, social co-creation strategies could be designed and translated to create business models and, respectively, to innovate processes in their companies in order to succeed. Our findings and their connections to the extant literature revealed that a lack of such strategies might lead to becoming less competitive in rendering innovative services.

\subsection{Theoretical Implications}

According to our findings, social media platforms help firms to receive feedback from customers and to enhance the innovativeness of their services, especially when the services are imitated from the previously successful innovations. Thus, the current model enables us to measure and to test which type(s) of social media platforms are more suitable and effective. Recent research has raised a similar debate on this issue, which is not clearly answered by the existing body of literature [119]. Thus, this research could open new windows of opportunity for conducting research in this domain.

In summary, firstly, this research contributes to the existing literature by empirically investigating and testing the relationship among the two dimensions of value co-creation behavior and innovative services, and showing the positive and negative moderating effect of social co-creation on two independent variables. Last but not least, it tests the model in a unique research population that is 
distinguished in terms of their performance and outcomes, such as innovative services that are imitated from previously successful innovations.

\subsection{Conclusions}

It can be concluded that the participation of customers in the innovated services plays a critical role in the success of the service providers to deliver that innovation to the markets. As shown by Hamidi et al. and Khajeheian and Friedrichsen [11,75], users and customers of services are major sources of innovative ideas and with the provision of a space for sharing their ideas and insights, firms will benefit from new sources of creativity and innovation. Today, versions of social platforms follow the logic of Web 3.0-that is, the logic of co-creation and collaboration; therefore, they provide a suitable space for accessing the use of customers' ideas as an external source of creativity. Currently, many enterprises and innovative service providers still use social platforms based on the logic of Web 2.0, which is mainly for connecting with customers, so the findings of this research reflects the necessity of moving to a co-creation space to go beyond the connection and to reach new ideas for innovative services, as well as more loyalty. Such co-creation is not necessarily a complicated and technical process, and can be conducted by the use of social media platforms for the co-creation of services, such as google docs, the logo building app, etc. This can even be done on the owned platforms of the firm by embedding new functions and possibilities that enable the customers to create an image or prototype of their ideas and also to share their experience with others. The findings also emphasize the encouragement of customer citizenship behavior (CCB) and customer participation behavior (CPB) to keep them as loyal customers. Some researchers identified the factors for encouraging co-creation behaviors in customers to keep them loyal, such as enjoyment, economic, and relational values [23]. The provision of respective values for customers can encourage co-creation behaviors and keep them loyal, and also increase the chance of their participation in innovative service development. This research contributes to the literature of co-creation on social platforms in the service sector: the area where our knowledge is poorly developed.

In summary, the findings of this research revealed that customer participation and citizenship behaviors positively affect the level of service innovativeness in the studied firms (H1 and H2). Excitingly, findings related to the following two hypotheses-i.e., H3 and H4-showed that although social co-creation moderated the previously mentioned relationship between independent and dependent variables, the direction of this moderating effect is not the same. That is to say that an increase in social co-creation activities positively affects the relationship between customer citizenship behavior and service innovativeness, and negatively affects the relationship between customer participation behavior and service innovativeness.

\subsection{Limitations and Future Research}

One of the limitations of this research was that there was not enough data available about how the innovative service providers actually used the co-creation behaviors of customers on social media, and if they had a certain strategy for the use of the co-creation ability of modern social media that enables them to do more than merely connect to customers. Another limitation was the difficulty of accessing a large pool of respective customers who are ready to take time and energy to carefully fill the online questionnaire in a cross-sectional survey. In addition to this, this research limits the imitative innovative services, whose core concepts have been copied from a previously successful service in other markets.

Future researchers might study the impact of different aspects of social co-creation on rendering innovative services beyond considering it as a moderating variable. The findings of such research could help researchers and practitioners focus on specific issues, such as peer pressure, popularity, trend, and social status. In this research, we mostly focused on some general hypotheses to open up new windows for those who would be interested in scrutinizing similar or more detailed research problems. 
Author Contributions: Conceptualization, A.M., S.R., A.S. and D.K.; methodology, P.E., A.S.; software, P.E.; validation, P.E., S.R., and A.S.; formal analysis, P.E.; investigation, A.M. and R.S.; resources, A.M. and D.K.; data curation, P.E.; writing — original draft preparation, A.S. and D.K.; writing-review and editing, A.S. and D.K.; visualization, P.E. and A.S.; supervision, A.M., S.R. and D.K.; project administration, D.K.; funding acquisition, D.K. All authors have read and agreed to the published version of the manuscript.

Funding: This research received no external funding.

Conflicts of Interest: The authors declare no conflict of interest.

\section{Appendix A. Research Questions}

\section{Customer Participation Behavior (Based on Yi \& Gong [87]).}

Information Seeking

1. I have asked others and searched for information on where this service is located and what it offers.

2. I have paid attention to how others behave to use this service well.

\section{Information Sharing}

3. I clearly explained what I wanted the employee to do and answered all the employee's service-related questions.

4. I gave the employee proper information and provided necessary information so that the employee could perform his or her duties.

\section{Responsible Behavior}

5. I performed all the tasks that are required and adequately completed all the expected behaviors.

6. I fulfilled responsibilities to the business and followed the employee's directives or orders.

\section{Personal Interaction}

7. I was friendly and kind to the employee.

8. I was polite and courteous to the employee.

Customer Citizenship Behavior (Based on Yi \& Gong [87]).

Feedback

9. If I have a useful idea on how to improve service, I let the employee know.

10. When I receive good service from the employee or experience a problem, I comment about and let them know it.

\section{Advocacy}

11. I said positive things about their services and the employee to others.

12. I recommended $X Y Z$ and the employee to others and encouraged friends and relatives to use their services.

\section{Helping}

13. I assist other customers if they need my help or seem to have problems.

14. I teach other customers to use the service correctly and give advice to other customers.

\section{Tolerance}

15. If service is not delivered as expected or on time, I would be willing to adapt. 
16. If the employee makes a mistake during service delivery, I would be willing to be patient.

\section{Service Innovativeness (Cheng et al. [91])}

17. Customers perceive the service feature as novel.

18. The benefits the service offers are new to the customers.

19. The service introduced many completely new features to the market.

20. The service shows an unconventional way of solving problems.

21. The service is brand new, never seen in the market before.

\section{Social Co-Creation (Based on Kennedy and Guzmán [101])}

22. I use my friends' recommendations on social media networks to become motivated and buy a service, and their behaviour is important for me.

23. Popularity of the individuals on social media networks makes me use similar services.

24. Current trends on social media networks makes me more engaged in those platforms and use specific services.

By increasing my social status on social media networks, I make more suggestions regarding services

\section{References}

1. Aquilani, B.; Silvestri, C.; Ioppolo, G.; Ruggieri, A. The challenging transition to bio-economies: Towards a new framework integrating corporate sustainability and value co-creation. J. Clean. Prod. 2018, 172, 4001-4009. [CrossRef]

2. Smyth, H.; Lecoeuvre, L.; Vaesken, P. Co-creation of value and the project context: Towards application on the case of Hinkley Point C Nuclear Power Station. Int. J. Proj. Manag. 2018, 36, 170-183. [CrossRef]

3. Ciasullo, M.V.; Troisi, O.; Cosimato, S. How Digital Platforms Can Trigger Cultural Value Co-Creation?-A Proposed Model. J. Serv. Sci. Manag. 2018, 11, 161-181.

4. Wiścicka-Fernando, M.; Misiak-Kwit, S.; Fernando, K.S.D. Co-Creation as an Innovative Way to Develop an Enterprise-Cross-Country Analysis. Sustainability 2019, 11, 6737. [CrossRef]

5. Kim, M.J.; Hall, C.M. Can co-creation and crowdfunding types predict funder behavior? An extended model of goal-directed behavior. Sustainability 2019, 11, 7061. [CrossRef]

6. Martínez-Cañas, R.; Ruiz-Palomino, P.; Linuesa-Langreo, J.; Blázquez-Resino, J.J. Consumer participation in co-creation: An enlightening model of causes and effects based on ethical values and transcendent motives. Front. Psychol. 2016, 7, 793. [CrossRef]

7. Caputo, F.; Garcia-Perez, A.; Cillo, V.; Giacosa, E. A knowledge-based view of people and technology: Directions for a value co-creation-based learning organisation. J. Knowl. Manag. 2019, 23, 1314-1334. [CrossRef]

8. Zhang, X.; Chen, R. Examining the mechanism of the value co-creation with customers. Int. J. Prod. Econ. 2008, 116, 242-250. [CrossRef]

9. Terho, H.; Haas, A.; Eggert, A.; Ulaga, W. 'It's almost like taking the sales out of selling'-Towards a conceptualization of value-based selling in business markets. Ind. Mark. Manag. 2012, 41, 174-185. [CrossRef]

10. Lambert, D.M.; Enz, M.G. Managing and measuring value co-creation in business-to-business relationships. J. Mark. Manag. 2012, 28, 1588-1625. [CrossRef]

11. Hamidi, F.; Shams Gharneh, N.; Khajeheian, D. A Conceptual Framework for Value Co-Creation in Service Enterprises (Case of Tourism Agencies). Sustainability 2020, 12, 213. [CrossRef]

12. Buhalis, D.; Sinarta, Y. Real-time co-creation and nowness service: Lessons from tourism and hospitality. J. Travel Tour. Mark. 2019, 36, 563-582. [CrossRef]

13. Franklin, D.; Marshall, R. Adding co-creation as an antecedent condition leading to trust in business-to-business relationships. Ind. Mark. Manag. 2019, 77, 170-181. [CrossRef] 
14. Zhang, T.C.; Jahromi, M.F.; Kizildag, M. Value co-creation in a sharing economy: The end of price wars? Int. J. Hosp. Manag. 2018, 71, 51-58. [CrossRef]

15. Yrjölä, M.; Kuusela, H.; Närvänen, E.; Rintamäki, T.; Saarijärvi, H. Leading change: A customer value framework. In Leading Change in a Complex World: Transdisciplinary Perspectives; Tampere University Press: Tampere, Finland, 2019.

16. Hamid, H. The Strategic Position of Human Resource Management for Creating Sustainable Competitive Advantage in the VUCA World. J. Hum. Resour. Manag. Labor Stud. 2019, 7, 1-4. [CrossRef]

17. Chauhan, A.; Joshi, M.; Kumar, A.; Abidi, S.; Dhiraj, A. Hindsight-insight-foresight: A strategic combination for enterprises in a VUCA world? Int. J. Technol. Transf. Commer. 2020, 17, 99-113.

18. Nair, J.; Pahurkar, R.; Phule, S. Changing face of the outsourcing industry in a VUCA world: Learning and Development Organizations the new frontier. Int. J. Res. Eng. Appl. Manag. 2019. [CrossRef]

19. Fathian, M.; Sharifi, H.; Solat, F. Investigating the Effect of Gamification Mechanics on Customer Loyalty in Online Stores. J. Inf. Technol. Manag. 2019, 11, 1-23.

20. Ruhnau, B. Eigenvector-centrality-A node-centrality? Soc. Netw. 2000, 22, 357-365. [CrossRef]

21. Merz, M.A.; Zarantonello, L.; Grappi, S. How valuable are your customers in the brand value co-creation process? The development of a Customer Co-Creation Value (CCCV) scale. J. Bus. Res. 2018, 82, 79-89. [CrossRef]

22. Zhang, T.; Lu, C.; Torres, E.; Chen, P.-J. Engaging customers in value co-creation or co-destruction online. J. Serv. Mark. 2018, 32, 57-69. [CrossRef]

23. Khajeheian, D.; Ebrahimi, P. Media branding and value co-creation: Effect of user participation in social media of newsmedia on attitudinal and behavioural loyalty. Eur. J. Int. Manag. 2020. [CrossRef]

24. Hoyer, W.D.; Chandy, R.; Dorotic, M.; Krafft, M.; Singh, S.S. Consumer cocreation in new product development. J. Serv. Res. 2010, 13, 283-296. [CrossRef]

25. Anaza, N.A. Personality antecedents of customer citizenship behaviors in online shopping situations. Psychol. Mark. 2014, 31, 251-263. [CrossRef]

26. Tain, J. Customer Engagement in Value Co-creation of Xiaomi: A Case Study. DEStech Trans. Soc. Sci. Educ. Hum. Sci. 2018. [CrossRef]

27. Radović-Marković, M.; Salamzadeh, A. The Nature of Entrepreneurship: Entrepreneurs and Entrepreneurial Activities; Lap Lambert Academic Publishing: Saarbrücken, Germany, 2012; ISBN 3659143111.

28. Salamzadeh, A.; Kawamorita Kesim, H. Startup companies: Life cycle and challenges. In Proceedings of the 4th International Conference on Employment, Education and Entrepreneurship (EEE), Belgrade, Serbia, 14-16 October 2015.

29. Grissemann, U.S.; Stokburger-Sauer, N.E. Customer co-creation of travel services: The role of company support and customer satisfaction with the co-creation performance. Tour. Manag. 2012, 33, 1483-1492. [CrossRef]

30. Iglesias, O.; Ind, N.; Alfaro, M. The organic view of the brand: A brand value co-creation model. In Advances in Corporate Branding; Springer: Berlin/Heidelberg, Germany, 2017; pp. 148-174.

31. Vázquez-Casielles, R.; Iglesias, V.; Varela-Neira, C. Co-creation and service recovery process communication: Effects on satisfaction, repurchase intentions, and word of mouth. Serv. Bus. 2017, 11, 321-343. [CrossRef]

32. Lorenzo-Romero, C.; Constantinides, E.; Brünink, L.A. Co-creation: Customer integration in social media based product and service development. Procedia Soc. Behav. Sci. 2014, 148, 383-396. [CrossRef]

33. Salvatian, S.; Labafi, S.; Soltani, T.; Khaki, A. Public Service Media and Entrepreneurial Use of Gamification for Knowledge Sharing inside Organization. Glob. Media J. Can. Ed. 2019, 10, 8-18.

34. Khajeheian, D.; Friedrichsen, M.; Mödinger, W. An introduction to competitiveness in fast changing business environment. In Competitiveness in Emerging Markets; Springer: Berlin/Heidelberg, Germany, 2018; pp. 3-11.

35. Emami, A.; Khajeheian, D. Social norms and entrepreneurial action: The mediating role of opportunity confidence. Sustainability 2019, 11, 158. [CrossRef]

36. Martinez, M.G. Co-creation of Value by Open Innovation: Unlocking New Sources of Competitive Advantage. Agribusiness 2014, 30, 132-147. [CrossRef]

37. Hervas-Oliver, J.-L.; Sempere-Ripoll, F.; Estelles-Miguel, S.; Rojas-Alvarado, R. Radical vs incremental innovation in Marshallian Industrial Districts in the Valencian Region: What prevails? Eur. Plan. Stud. 2019, 27, 1924-1939. [CrossRef] 
38. Yen, C.H.; Teng, H.Y.; Tzeng, J.C. Innovativeness and customer value co-creation behaviors: Mediating role of customer engagement. Int. J. Hosp. Manag. 2020, 88, 102514. [CrossRef]

39. Fuchs, C. Social Media: A Critical Introduction; Sage: London, UK, 2017; ISBN 1473987490.

40. Hang, M. Media and Entrepreneurship, A Revisit with a Decade of Progress: A Bibliometric Analysis of Media Entrepreneurship Research Between 2005 and 2017. Nord. J. Media Manag. 2020, 1, 187-207.

41. Dal Zotto, C.; Omidi, A. Platformization of Media Entrepreneurship: A Conceptual Development. Nord. J. Media Manag. 2020, 209-233. [CrossRef]

42. Rroshandel Arbatani, T.; Kawamorita, H.; Ghanbary, S.; Ebrahimi, P. Modelling media entrepreneurship in social media: SEM and MLP-ANN Approach. AD Minist. 2019, 35-57. [CrossRef]

43. Khajeheian, D. Telecommunication Policy: Communication Act Update. Glob. Media J. 2016, 9, $135-143$.

44. Salamzadeh, Y.; Williams, I.; Labafi, S. Guest Editorial: Media Entrepreneurship and Web 3.0, the way passed, the way forward. AD Minist. 2019, 34, 7-13.

45. Doshmanli, M.; Salamzadeh, Y.; Salamzadeh, A. Development of SMEs in an emerging economy: Does corporate social responsibility matter? Int. J. Manag. Enterp. Dev. 2018, 17, 168-191. [CrossRef]

46. Labafi, S.; Williams, I. Competitiveness of small media firms. In Competitiveness in Emerging Markets; Springer: Berlin/Heidelberg, Germany, 2018; pp. 263-282.

47. Seyyedamiri, N.; Tajrobehkar, L. Social content marketing, social media and product development process effectiveness in high-tech companies. Int. J. Emerg. Mark. 2019. [CrossRef]

48. Roshandel Arbatani, T.; Norouzi, E.; Omidi, A.; Valero-Pastor, J.M. Competitive strategies of mobile applications in online taxi services. Int. J. Emerg. Mark. 2019. [CrossRef]

49. Achtenhagen, L. Media Entrepreneurship-Taking Stock and Moving Forward. JMM Int. J. Media Manag. 2017, 19, 1-10. [CrossRef]

50. Achtenhagen, L. Entrepreneurial orientation-An overlooked theoretical concept for studying media firms. Nord. J. Media Manag. 2020, 1, 7-21.

51. Powers, A.; Zhao, J. Staying alive: Entrepreneurship in family-owned media across generations. Balt. J. Manag. 2019, 14, 641-657. [CrossRef]

52. Girija, S. Political economy of media entrepreneurship: Commercialization and Commodification in a digital news media enterprise. J. Media Manag. Entrep. 2019, 1, 27-39. [CrossRef]

53. Tajeddin, M.; Emami, A.; Rastgar, A.A. Social networks of immigrant entrepreneurs in media industry: The case of Iranian immigrants in Canada. In Competitiveness in Emerging Markets; Springer: Berlin/Heidelberg, Germany, 2018; pp. 123-144.

54. Salamzadeh, A.; Kirby, D.A. New venture creation: How start-ups grow? AD Minist. 2017, 30, 9-29. [CrossRef]

55. Salamzadeh, A. Start-up boom in an emerging market: A niche market approach. In Competitiveness in Emerging Markets; Springer: Berlin/Heidelberg, Germany, 2018; pp. 233-243.

56. Horst, S.-O.; Murschetz, P.C. Strategic media entrepreneurship: Theory development and problematization. J. Media Manag. Entrep. 2019, 1, 1-26. [CrossRef]

57. Jahanshahi, A.A.; Brem, A. Entrepreneurs in post-sanctions Iran: Innovation or imitation under conditions of perceived environmental uncertainty? Asia Pacific J. Manag. 2019, 37, 531-551. [CrossRef]

58. Guerrero, M.; Urbano, D. Effectiveness of technology transfer policies and legislation in fostering entrepreneurial innovations across continents: An overview. J. Technol. Transf. 2019, 44, 1347-1366. [CrossRef]

59. Omri, A. Formal versus informal entrepreneurship in emerging economies: The roles of governance and the financial sector. J. Bus. Res. 2020, 108, 277-290. [CrossRef]

60. Reillier, L.C.; Reillier, B. Platform Strategy: How to Unlock the Power of Communities and Networks to Grow Your Business; Taylor \& Francis: Abingdon, UK, 2017; ISBN 1317085515.

61. Parker, G.G.; Van Alstyne, M.W.; Choudary, S.P. Platform Revolution: How Networked Markets Are Transforming the Economy? and How to Make Them Work for You; WW Norton \& Company: New York, NY, USA, 2016; ISBN 0393249123.

62. Hossain, S.F.A. Social networking and its role in media entrepreneurship: Evaluating the use of mobile phones in the context of online shopping-A review. J. Media Manag. Entrep. 2019, 1, 73-86. [CrossRef] 
63. Khajeheian, D.; Colabi, A.M.; Shah, A.K.; Binti, N.; Radzi, B.W.M.; Jasimah, C.W.; Jenatabadi, H.S. Effect of social media on child obesity: Application of structural equation modeling with the Taguchi method. Int. J. Environ. Res. Public Health 2018, 15, 1343. [CrossRef] [PubMed]

64. Hefler, M.; Kerrigan, V.; Henryks, J.; Freeman, B.; Thomas, D.P. Social media and health information sharing among Australian Indigenous people. Health Promot. Int. 2019, 34, 706-715. [CrossRef] [PubMed]

65. Stellefson, M.; Paige, S.R.; Chaney, B.H.; Chaney, J.D. Social Media and Health Promotion 2020. Int. J. Environ. Res. Public Health 2020, 17, 3323. [CrossRef] [PubMed]

66. Gao, J.; Zheng, P.; Jia, Y.; Chen, H.; Mao, Y.; Chen, S.; Wang, Y.; Fu, H.; Dai, J. Mental health problems and social media exposure during COVID-19 outbreak. PLOS ONE 2020, 15, e0231924. [CrossRef] [PubMed]

67. Ebrahimi, P.; Hajmohammadi, A.; Khajeheian, D. Place branding and moderating role of social media. Curr. Issues Tour. 2020, 23, 1723-1731. [CrossRef]

68. Dolan, R.; Seo, Y.; Kemper, J. Complaining practices on social media in tourism: A value co-creation and co-destruction perspective. Tour. Manag. 2019, 73, 35-45. [CrossRef]

69. Fukui, M.; Ohe, Y. Assessing the role of social media in tourism recovery in tsunami-hit coastal areas in Tohoku, Japan. Tour. Econ. 2019, 17, 3323. [CrossRef]

70. Mehraliyev, F.; Choi, Y.; Koseoglu, M.A. Social structure of social media research in tourism and hospitality. Tour. Recreat. Res. 2019, 44, 451-465. [CrossRef]

71. Murschetz, P.C.; Prandner, D. Datafying broadcasting: Exploring the role of big data and its implications for competing in a big data-driven tv ecosystem. In Competitiveness in Emerging Markets; Springer: Berlin/Heidelberg, Germany, 2018; pp. 55-71.

72. Marashi, P.S.; Hamidi, H. Business challenges of big data application in health organization. In Competitiveness in Emerging Markets; Springer: Berlin/Heidelberg, Germany, 2018; pp. 569-584.

73. Nemati, S.; Khajeheian, D. Big data for competitiveness of SMEs: Use of consumer analytic to identify niche markets. In Competitiveness in Emerging Markets; Springer: Berlin/Heidelberg, Germany, 2018; pp. 585-599.

74. Oliver, J. Dynamic capabilities and superior firm performance in the UK media industry. J. Media Bus. Stud. 2014, 11, 57-78. [CrossRef]

75. Khajeheian, D.; Friedrichsen, M. Innovation inventory as a source of creativity for interactive television. In Digital Transformation in Journalism and News Media; Springer: Berlin/Heidelberg, Germany, 2017; pp. 341-349.

76. Estiri, M.; Amiri, N.S.; Khajeheian, D.; Rayej, H. Leader-member exchange and organizational citizenship behavior in hospitality industry: A study on effect of gender. Eurasian Bus. Rev. 2018, 8, 267-284. [CrossRef]

77. Ahn, J.-W.; Chun, M.-H. Influence of perceived friendship on customer participation behavior and customer citizenship behavior as well as customer cooperation. Manag. Inf. Syst. Rev. 2016, 35, 155-172.

78. Baines, N.; Smith, H.L. Key driving factors for product and service innovations in UK university spin-offs. Ind. High. Educ. 2019, 33, 161-171. [CrossRef]

79. Edvardsson, B.; Tronvoll, B.; Gruber, T. Expanding understanding of service exchange and value co-creation: A social construction approach. J. Acad. Mark. Sci. 2011, 39, 327-339. [CrossRef]

80. Vargo, S.L.; Lusch, R.F. From repeat patronage to value co-creation in service ecosystems: A transcending conceptualization of relationship. J. Bus. Mark. Manag. 2010, 4, 169-179. [CrossRef]

81. Vargo, S.L.; Maglio, P.P.; Akaka, M.A. On value and value co-creation: A service systems and service logic perspective. Eur. Manag. J. 2008, 26, 145-152. [CrossRef]

82. Sharafi Farzad, F.; Kolli, S.; Soltani, T.; Ghanbary, S. Digital Brands and Web 3.0 Enterprises: Social Network Analysis and Thematic Analysis of User activities and Behavioral Patterns in Online Retailers. AD Minist. 2019, 119-138. [CrossRef]

83. Khajeheian, D. Enterprise social media: Ethnographic research on communication in entrepreneurial teams. Int. J. E Serv. Mob. Appl. 2018, 10, 34-46. [CrossRef]

84. Xie, C.; Bagozzi, R.P.; Troye, S.V. Trying to prosume: Toward a theory of consumers as co-creators of value. J. Acad. Mark. Sci. 2008, 36, 109-122. [CrossRef]

85. Joung, J.; Jung, K.; Ko, S.; Kim, K. Customer complaints analysis using text mining and outcome-driven innovation method for market-oriented product development. Sustainability 2019, 11, 40. [CrossRef]

86. Shamim, A.; Ghazali, Z. A Conceptual Model for Developing Customer Value Co-Creation Behaviour in Retailing. Glob. Bus. Manag. Res. 2014, 6, 185-196. 
87. Yi, Y.; Gong, T. Customer value co-creation behavior: Scale development and validation. J. Bus. Res. 2013, 66, 1279-1284. [CrossRef]

88. Cheng, C.C.; Chen, J.; Tsou, H.T. Market-creating service innovation: Verification and its associations with new service development and customer involvement. J. Serv. Mark. 2012, 26, 444-457. [CrossRef]

89. Yang, M.H.; Weng, S.S.; Hsiao, P.I. Measuring blog service innovation in social media services. Internet Res. 2014, 24, 110-128. [CrossRef]

90. Hertog, P. Knowledge-Intensive Business Services as Co-Producers of Innovation. Int. J. Innov. Manag. 2000, 4, 491-528. [CrossRef]

91. Cheng, C.C.J.; Shiu, E.C.C.; Dawson, J.A. Service business model and service innovativeness. Int. J. Innov. Manag. 2014, 18, 1450013. [CrossRef]

92. Aggarwal, N. Investigating Moderating Role of Customer Participation in Customer-based Corporate Reputation and Customer Citizenship Behavior. FIIB Bus. Rev. 2014, 3. [CrossRef]

93. Heidenreich, S.; Handrich, M. Adoption of technology-based services: The role of customers' willingness to co-create. J. Serv. Manag. 2015, 26, 44-71. [CrossRef]

94. Jaakkola, E.; Alexander, M. The Role of Customer Engagement Behavior in Value Co-Creation: A Service System Perspective. J. Serv. Res. 2014, 17, 247-261. [CrossRef]

95. van Tonder, E.; Saunders, S.G.; Lisita, I.T.; de Beer, L.T. The importance of customer citizenship behaviour in the modern retail environment: Introducing and testing a social exchange model. J. Retail. Consum. Serv. 2018, 45, 92-102. [CrossRef]

96. Nambisan, P.; Nambisan, S. Models of consumer value cocreation in health care. Health Care Manag. Rev. 2009, 34, 344-354. [CrossRef]

97. Hwang, J.; Lee, J.S.; Kim, H. Perceived innovativeness of drone food delivery services and its impacts on attitude and behavioral intentions: The moderating role of gender and age. Int. J. Hosp. Manag. 2019, 81, 94-103. [CrossRef]

98. Buhalis, D.; Foerste, M. SoCoMo marketing for travel and tourism: Empowering co-creation of value. J. Destin. Mark. Manag. 2015, 4, 151-161. [CrossRef]

99. Rathore, A.K.; Ilavarasan, P.V.; Dwivedi, Y.K. Social media content and product co-creation: An emerging paradigm. J. Enterp. Inf. Manag. 2016, 29, 7-18. [CrossRef]

100. Salamzadeh, A.; Radovic Markovic, M.; Masjed, S.M. The Effect of Media Convergence on Exploitation of Entrepreneurial Opportunities. AD Minist. 2019, 59-76. [CrossRef]

101. Kennedy, E.; Guzmán, F. Co-creation of brand identities: Consumer and industry influence and motivations. J. Consum. Mark. 2016, 33, 313-323. [CrossRef]

102. Kang, J.-Y.M. Repurchase loyalty for customer social co-creation e-marketplaces. J. Fash. Mark. Manag. 2014, 18, 452-464. [CrossRef]

103. Roberts, D.; Hughes, M.; Kertbo, K. Exploring consumers' motivations to engage in innovation through co-creation activities. Eur. J. Mark. 2014, 48, 147-169. [CrossRef]

104. Ebrahimi, P.; Shirsavar, H.R.A.; Forootani, F.; Roohbakhsh, N.; Ebrahimi, K. Entrepreneurship and SMEs performance: Studying the mediating role of innovation and the moderating role of firm size. In Competitiveness in Emerging Markets; Springer: Cham, Switzerland, 2018.

105. Ebrahimi, P.; Shafiee, B.; Gholampour, A.; Yousefi, L. Impact of organizational innovation, learning orientation and entrepreneurship on SME performance: The moderating role of market turbulence and ICT. In Competitiveness in Emerging Markets; Springer: Cham, Switzerland, 2018.

106. Hair, J.F., Jr.; Hult, G.T.M.; Ringle, C.; Sarstedt, M. A Primer on Partial Least Squares Structural Equation Modeling (PLS-SEM); Sage publications: Thousand Oaks, CA, USA, 2016; ISBN 1483377466.

107. Ebrahimi, P.; Mirbargkar, S.M. Green entrepreneurship and green innovation for SME development in market turbulence. Eurasian Bus. Rev. 2017, 7, 203-228. [CrossRef]

108. Sanchez, G. PLS path modeling with R. Berkeley Trowchez Ed. 2013, 383, 2013.

109. Fornell, C.; Larcker, D.F. Evaluating Structural Equation Models with Unobservable Variables and Measurement Error. J. Mark. Res. 1981, 18, 39-50. [CrossRef]

110. Geisser, S. A Predictive Approach to the Random Effect Model. Biometrika 1974, 61, 101-107. [CrossRef]

111. Stone, M. Cross-validatory choice and assessment of statistical predictions. J. R. Stat. Soc. Ser. B 1974, 36, 111-133. [CrossRef] 
112. Ebrahimi, P.; Ahmadi, M.; Gholampour, A.; Alipour, H. CRM performance and development of media entrepreneurship in digital, social media and mobile commerce. Int. J. Emerg. Mark. 2019. [CrossRef]

113. Koelling, M.; Neyer, A.K.; Moeslein, K.M. Strategies towards innovative services: Findings from the German service landscape. Serv. Ind. J. 2010, 15, 609-620. [CrossRef]

114. Rajala, R.; Gallouj, F.; Toivonen, M. Introduction to the special issue on multiactor value creation in service innovation: Collaborative value creation in service. Serv. Sci. 2016, 3, 249-357. [CrossRef]

115. Chen, J.S.; Kerr, D.; Chou, C.Y.; Ang, C. Business co-creation for service innovation in the hospitality and tourism industry. Int. J. Contemp. Hosp. Manag. 2017, 29, 1522-1540. [CrossRef]

116. Bidar, R. Service Co-Creation Behaviour in Actor-to-Actor Co-Creation Systems: From Service-Dominant Logic to Socio-Service Dominant Logic; Queensland University of Technology Press: Brisbane, Australia, 2018.

117. Zhang, P. Co-Creation Experience: Measurement Development and Influence on Value in Sharing Economy. Adv. Appl. Sociol. 2017, 7, 151-164. [CrossRef]

118. Binti Ishak, N.A. Enacting Organisational and Consumer Value Capture: A Social Co-Creation Perspective; Brunel University: London, UK, 2018.

119. Olanrewaju, A.-S.T.; Hossain, M.A.; Whiteside, N.; Mercieca, P. Social media and entrepreneurship research: A literature review. Int. J. Inf. Manag. 2020, 50, 90-110. [CrossRef]

(C) 2020 by the authors. Licensee MDPI, Basel, Switzerland. This article is an open access article distributed under the terms and conditions of the Creative Commons Attribution (CC BY) license (http://creativecommons.org/licenses/by/4.0/). 